\title{
Normalitetens grenser, pris og alternativer - funksjonshemning som levd realitet
}

\author{
Hva er viktig når man har brukket ryggen, fått livet snudd opp ned og ser for seg en fremtid som funksjons- \\ hemmet? Hvilke tenkemåter gir mening og retning for livet? Hvilke mål og normer stilles opp i helsevesen, \\ velferdsordninger og politikk? I Norge har normalitet og inklusjon vært uomstridte mål og prinsipper i over \\ førti år. Like fullt diskuterer man fremdeles gapet mellom idealer og realiteter.
}

\section{Ingunn Moser}

moser@diakonhjemmet.no

Diakonhjemmet Høgskole

og

Universitetet i Nordland

Fra tidlig i 1960-årene ble det i Norge arbeidet for å etablere en samlet offentlig politikk overfor funksjonshemmede, og for at denne skulle baseres på integrering og normalisering. I årtiene etter er det bygd opp et omfattende velferdsstatlig apparat for å sikre funksjonshemmede muligheten til å leve et normalt liv. Strategien for å realisere dette målet har vært å kompensere økonomisk, teknisk og sosialt for det gapet mellom individuelle evner og samfunnets krav til funksjon som funksjonshemningen er blitt forstått som.

\section{Normalitet som norm og mål}

I dag har normalisering blitt et negativt ladet ideal, men normalitet og inkludering er fremdeles mål for politikken overfor funksjonshemmede. Å ha normalitet som norm er imidlertid et gode med en svært høy pris. For hvordan virker dette idealet? Normalitet forutsetter per definisjon en grense og noe på den ande siden. Alt kan ikke være eller bli normalt. Det normale baserer seg på, og er avhengig av, noe som ikke er normalt. Med et bilde kan man si at målet om normalitet virker som en evighetsmaskin som i det stille fortsetter å produsere de forskjellene som i neste omgang må inkluderes og normaliseres. Bestrebelser på å normalisere kan derfor aldri lykkes. Det vil si, de kan nok dyktiggjøre funksjonshemmede på ett nivå, men på samme tid bidrar de også til å hemme, gjennom å være med på å produsere større avstand til normalitet og sementere de utgangsbetingelsene man ønsker å endre.

Gitt den intensiverte innsatsen for å skape normalitet, må ikke bestrebelsene, når normaliseringens pris blir for høy for dem som må bære kostnadene, også bære kimen i seg til noe annet? Den intensiverte normaliseringen bidrar jo også til at reproduksjonen av det ikke-normale forsterkes. Grensene for normalisering blir tydeligere. Da reises spørsmålet om andre mulige måter å gi livet form og retning - uavhengig av normalisering.

\section{Normer, normalitet og avvik i medisinsk praksis}

Er ikke både normalitet og avvik, og med dem også normene for organismers liv, gitt? Er det ikke nettopp det medisinen holder på med: å identifisere normer og normaler, og så behandle med sikte på å gjenopprette og opprettholde et nivå som rett og slett for livets skyld, for livet selv, er og må være innenfor det normale? Eller - hvilke forbindelser er det mellom normene og den normalitet som medisinen etterstreber, og de som hevdes i politikken eller av funksjonshemmede selv og deres talsmenn?

I The normal and the pathological hevdet

$$
\begin{aligned}
& \text { «Vi må erkjenne at } \\
& \text { funksjonsdyktig og } \\
& \text { funksjonshemmet ikke } \\
& \text { er en dikotomi mellom } \\
& \text { to gitte enheter» }
\end{aligned}
$$

den franske vitenskaps- og medisinhistorikeren Georges Canguilhem (1904-95) at patologi først og fremst er en levd realitet, og dermed et spørsmål om relasjonen mellom organismen og dens omgivelser (1). På den bakgrunn forsvarte han den kliniske normaliteten mot normene fra laboratoriet. Det betyr ifølge filosofen Annemarie Mols utlegning at avvik ikke er et positivt faktum, og at forskjellen på det som er normalt og avvikende ikke kan slås fast i mikroskopet (2). Å måle variabler hos en isolert organisme kan gi mye kunnskap, men sier ikke noe om når helse slår over i sykdom. Avvik er også en verdi, og denne verdien kommer fra forholdet mellom organismen og dens omgivelser. Avvik er følgelig normativt og verken nøytralt eller gitt.

Michel Foucault (1926-84), var student av Canguilhem. Han la vekten på at medisinsk kunnskap, som altså identifiserer og bestreber seg på å opprettholde visse normer gjennom behandling og pleie, også aktivt er med på å sette normer. Gjennom å hevde normaliteten som norm blir medisinen også delaktig i styringen - normaliseringen - av det samfunnet den er del av (3). Medisinsk kunnskap er i livet og verden, vel så mye som om livet og verden.

Til forskjell fra sin student var Georges Canguilhem imidlertid mer opptatt av organismens eget potensial til å fastsette normer gjennom å respondere kreativt på endringer i omgivelsene. For ham var det dette som markerte liv og orden - i motsetning til død og kaos. Det innebærer imidlertid at normer er lokale og foranderlige, og verken universelle, objektive eller gitte. Det innebærer også at det ikke finnes vitenskapelige måter å etablere hvilke normer som skal gjelde. Slike utfordringer må håndteres innenfor rammen av det levde liv og spørsmålet om hva slags liv vi vil leve.

\section{Medisinens makt og dominans?}

Denne argumentasjonen har vært grunnlag for mye samfunnsvitenskapelig kritikk av medisinens dominans, av den såkalte medikaliseringen av livet og samfunnet (4). Kritikken har dels gått på at medisinen ekspanderer og sykeliggjør stadig flere problemer og tilstander som hører livet til, dels på måten den medisinske modellen individualiserer og naturaliserer både sykdommene, tilstandene, funksjonshemningene og normene. Ved å fokusere på avvik, den enkeltes kropp og begrensninger rettes innsatsen mot det å kompensere for individualiserte mangler, heller enn mot å endre samfunnets krav og innordninger. Når en slik medisinsk betraktningsmåte også blir lagt til grunn for definisjonen og tenkningen om funksjonshemning i politikken overfor funksjonshemmede, blir medisinenen regulerende og normaliserende makt. 


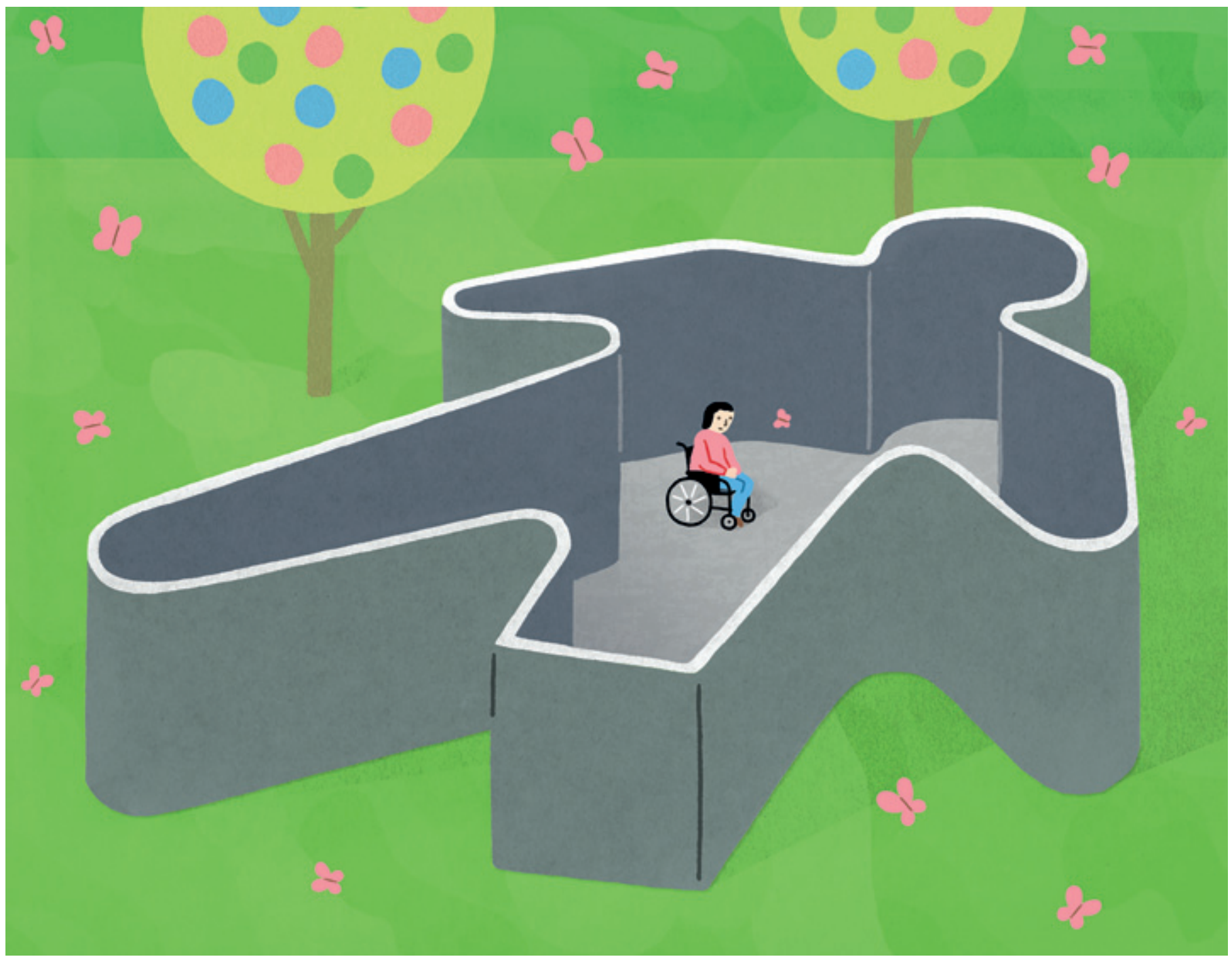

Illustrasjon Svein Størksen

Innenfor forskning om funksjonshemninger, det som internasjonalt går under navnet disability studies, har man skapt et rom for å utforske dette fenomenet innenfor andre rammer enn de medisinske. Siktemålet her har lenge vært å denaturalisere funksjonshemning, og vise hvordan funksjonshemning får mening og blir ordnet $\mathrm{og}$ formet $\mathrm{i}$ ulike institusjonelle sammenhenger som rehabiliteringsopplegg, byråkratiske kategorier, velferdsstatens tiltak og virkemidler, politiske plandokumenter, fysiske infrastrukturer og medier.

Imidlertid har man ofte basert seg på en problematisk slutning om at tenkemåter og kunnskapsformer, og da spesielt den medisinske disiplinens, får gjennomslag mer eller mindre av seg selv. Man har antatt at de ikke bare former måten folk tenker på, men hvordan dette også materialiserer seg i kroppen og ulike praksiser, institusjoner og politikk, og at de gjør det på en koherent måte. Er det nødvendigvis slik? Hvor får medisinen i tilfelle en slik disiplinerende makt fra? Og hva når menneskene flytter ut av institusjonene og tilbake til hverdagen, hvor de medisinske normene møter andre normer og idealer? Hvilke tenkemåter mobiliserer funksjonshemmede, og hvilke måter å leve på skaper de - i normalitetens grenseland?

\section{Funksjonshemning \\ og mangfold i hverdagen}

I doktorgradsarbeidet mitt om livet etter en trafikkskade utforsket jeg hvordan livet ordnes på nytt som funksjonshemmet (5).

En trafikkulykke innebærer ofte at livet blir radikalt omkalfatret. Trafikkskadede er derfor bedre enn de fleste i stand til å sette ord på hva det innebærer å bli funksjonshemmet. Med dette utgangspunktet undersøkte jeg hvilke nye forventninger og normer de trafikkskadede blir møtt med, og også stiller opp for seg selv; og hvilke tenkemåter som mobiliseres for å gi livet med funksjonshemning mening og retning. For dette formål valgte jeg å ta utgangspunkt i hverdagslivet - å studere empirisk hvordan livet etter en ulykke blir ordnet på nytt «nedenifra», der hvor samfunnets institusjoner viser seg i og gjennom daglige praksiser. Dermed valgte jeg bevisst ikke å ta utgangspunkt $\mathrm{i}$ enten medisinen eller den offisielle politikken overfor funksjonshemmede. Mange studier gjør nettopp det, og antar uproblematisk at de får gjennomslag, slik at man kan slutte fra deres definisjoner og planer til hvordan virkeligheten er eller har vært. Mitt ærend har heller vært å undersøke om, og i tilfelle hvordan, medisinen og politikken trer inn og virker i hverdagslivet, å utforske hvilke andre tenkemåter som er i arbeid der, og hvordan disse ulike måtene å ordne livet på kan virke side om side.

Slik kan man også lete etter tendenser til endring og alternative muligheter i hverdagslivet. Datamaterialet fra avhandlingen viser for eksempel at for noen kan det å rehabilitere skjebnen skape et frirom, en mulighet til tilbaketrekning fra de bortimot umulige kravene om aktivitet og planer, utdanning og arbeid, uavhengighet og mestring. Det å akseptere det man ikke rår med omdefineres fra en mangel til en positiv verdi og en dyd. Likeledes det å erkjenne at mange, om ikke de fleste, ting i livet er 
resultat av omstendigheter, tilfeldigheter og hendelser utenfor vår kontroll. Erkjennelsen som ligger bak er at om man forventer at livet skal være et prosjekt eller en karriere som kan planlegges, så vil man være dømt til å mislykkes eller være evig skuffet. Hvis man i stedet lærer å ta en dag om gangen og unngår å gjøre alt til midler for andre og større mål, så kan man bli i stand til å glede seg over livet og være fornøyd.

Datamaterialet fra avhandlingen viser imidlertid også at mange strever mye for å prøve å leve opp til kravene om normalitet - med resulterende stor fallhøyde og personlig risiko. De prioriterer beinhardt for å studere med normal progresjon og beste resultater, samtidig som de må stå opp et par timer tidligere for å greie morgenritualene og samordne seg med hjemmetjenestene eller transporten slik at de kan være på plass når forelesningene begynner. De prioriterer bort venner, sosialt liv og endatil den helt nødvendige treningen for å «holde systemet i funksjon», og pådrar seg sittesår og smerter. Alt dette for å greie å holde tritt, først i studier og så i arbeid, inntil de «møter veggen» og opplever at all planlegging, prioritering og selvbestemmelse til tross så strekker de ikke til; de mislykkes.

Noen finner likevel en utvei i en pasjonslogikk, en måte å leve livet på som styres av helt andre verdier enn de normene normaliseringen har satt opp for oss. Når de må gi opp å kunne leve opp til arbeidslivets krav, gir de seg lidenskapen i vold i stedet. De styres av og lever for sin pasjon, for eksempel ekstremsport, livet på nettet eller kreativ skriving. For dem er det ikke så mye autonomi og uavhengighet som gjelder lenger, men heller hengivelse eller besettelse: det å bli drevet av og forsvinne inn i noe annet som betyr alt, blir «ens prosjekt» eller bestemmelse, og fyller livet med mening i seg selv.

\section{Normalitetens grenser og alternativer}

Kritikk av normaliseringens sosiale konsekvenser er i og for seg viktig. Bare kritikk kan imidlertid bidra til å gjøre dynamikken med en normal og den mangel den produserer, viktigere enn den faktisk er. Normalitetens pris er ganske visst høy, det koster å leve opp til normen, og det koster i mange tilfeller også for mye. Imidlertid finnes det faktisk andre idealer og måter å leve et godt liv på, idealer og måter som praktiseres i folks hverdagsliv. Det kan både politikken og medisinen lære noe av. Den politikken som har vært ført overfor funksjonshemmede i snart 40 år har vært basert på en individualiserende og naturaliserende definisjon av funksjonshemning som et gap mellom individuelle forutsetninger og samfunnsmessige krav. Logikken har vært at det er den enkelte som må kompenseres for sine manglende forutsetninger heller enn at kravene må endres. Vi må erkjenne at funksjonsdyktig og funksjonshemmet ikke er en dikotomi mellom to gitte enheter. I stedet er det slik at folk blir gjort funksjonsdyktige og funksjonshemmet på mange måter og i mange situasjoner, i relasjonen mellom organisme og omgivelser. Derfor bør man ikke basere seg på kompensasjon som strategi. Man kunne heller prøve ut mer inkluderende strategier med rom for forskjeller i stedet for å søke å kompensere for, utviske og avskaffe dem.

\section{Ingunn Moser (f. 1965)}

er rektor/professor ved Diakonhjemmet Høgskole, professor II ved Universitetet i Nordland, professor i sosiologi med vekt på sosiale studier av vitenskap, teknologi og medisin. Ingen oppgitte interessekonflikter.

\section{Litteratur}

1. Canguilhem, G. The normal and the pathological. New York: Zone Books, 1989.

2. Mol A. Lived reality and the multiplicity of norms: a critical tribute to Georges Canguilhem. Economy and Society 1998; 27: 274-84.

3. Foucault M. Discipline and punish: the birth of the prison. Harmondsworth: Penguin, 1979.

4. Illich I. Medical nemesis. London: Calder and Boyars, 1975.

5. Moser I. Road traffic accidents: the ordering of subjects, bodies and disability. Doktoravhandling. Oslo: Senter for teknologi, innovasjon og kultur, Universitetet i Oslo/Unipub, 2003.

Mottatt 10.1. 2011, første revisjon innsendt 30.1. 2010, godkjent 3.2. 2011. Medisinsk redaktør Are Brean. 